
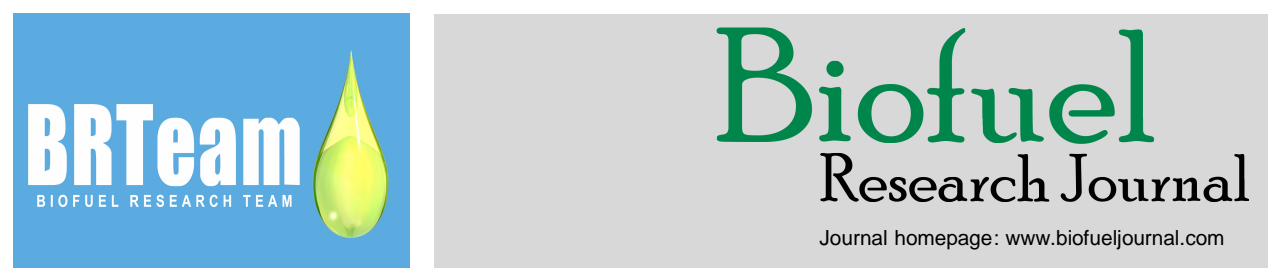

Original Research Paper

\title{
Deciphering acidogenic process towards biohydrogen, biohythane, and short chain fatty acids production: multi-output optimization strategy
}

Omprakash Sarkar, S. Venkata Mohan *

Bioengineering and Environmental Sciences (BEES), CSIR-Indian Institute of Chemical Technology (CSIR-IICT), Hyderabad 500 007, India.

\section{HIGHLIGHTS}

$>$ Taguchi DOE methodology was used to optimize acidogenic process.

$>$ Pretreated biocatalyst and higher COD had significant role in $\mathrm{H}_{2}$ and VFA production $>$ The application of untreated biocatalyst was more favorable for biohythane production.

$>$ Higher degree of acidification (DOA) was achieved at higher organic loads.

\section{GRAPHICAL ABSTRACT}

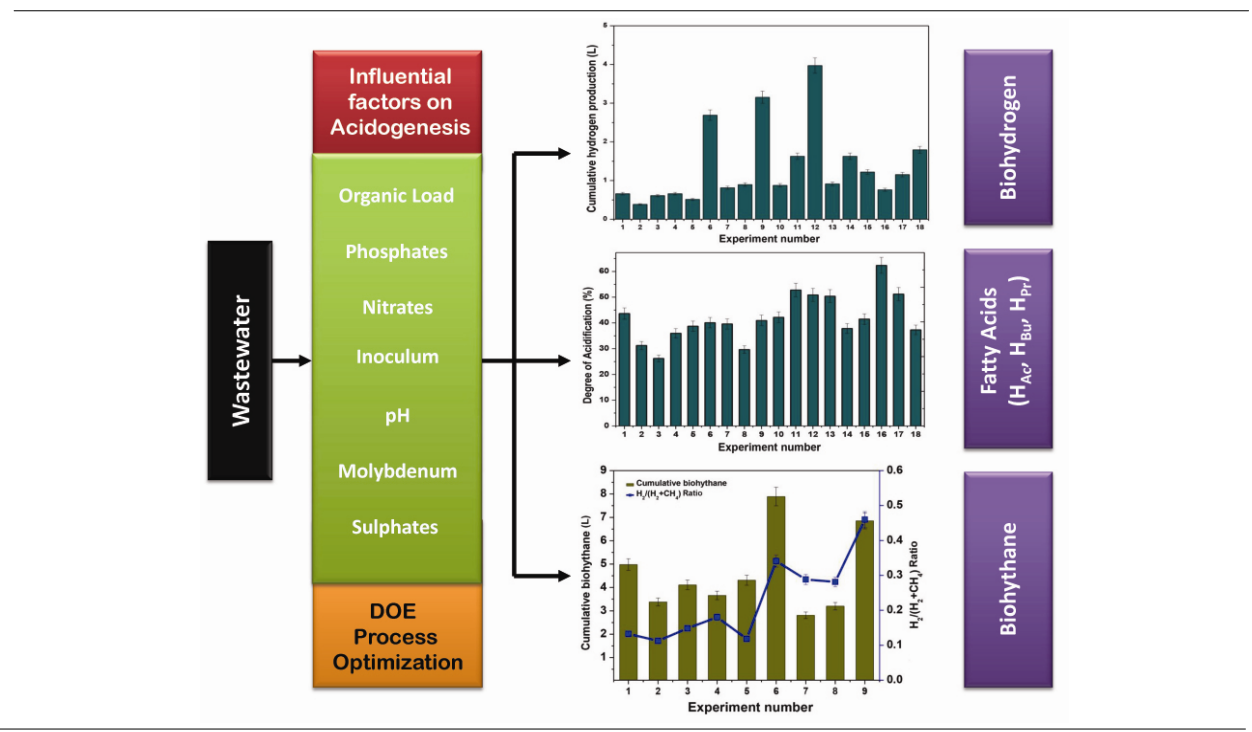

\section{ARTICLE INFO}

\section{Article history:}

Received 11 June 2016

Received in revised form 9 August 2016

Accepted 11 August 2016

Available online 1 September 2016

\section{Keywords:}

Acidogenic process

Biohydrogen

Biohythane

Volatile fatty acids

Waste remediation

Optimization

\begin{abstract}
Optimization of process parameters is crucial to understand the acidogenic fermentation process and its regulation towards the production of specific metabolites, viz., biohydrogen $\left(\mathrm{H}_{2}\right)$, methane $\left(\mathrm{CH}_{4}\right)$, biohythane $\left(\mathrm{H}_{2}+\mathrm{CH}_{4}\right)$, and volatile fatty acids (VFA). Design of experiments (DOE) based on orthogonal array (OA) was employed to optimize and evaluate the influence of eight critical factors on multiple metabolic output parameters. Analysis of the experimental data revealed a specific influential regime of selected factors in terms of biogas generation and/or VFA synthesis. Application of pretreated inoculum as biocatalyst and high substrate concentration showed substantial enhancement of both $\mathrm{H}_{2}$ and VFA production. High COD of $10 \mathrm{~g} / \mathrm{L}$ in combination with pretreated inoculum resulted in higher cumulative hydrogen production (CHP), while the higher fraction of acetic acid in the fermentation broth resulted in a higher degree of acidification (DOA). $\mathrm{H}_{2} / \mathrm{H}_{2}+\mathrm{CH}_{4}$ ratio varied from 0.1 to 0.97 and the application of untreated inoculum was shown to favor biohythane $\left(\mathrm{H}_{2}+\mathrm{CH}_{4}\right)$ production. Overall, this communication holistically documented the feasibility of regulating acidogenic fermentation process towards a spectrum of metabolic end products of high value, while waste treatment was also achieved.
\end{abstract}

(C) 2016 BRTeam. All rights reserved.

* Corresponding author at: Tel.: +91 4027161765

E-mail address: vmohan_s@yahoo.com

Please cite this article as: Sarkar O., Venkata Mohan S. Deciphering acidogenic process towards biohydrogen, biohythane and short chain fatty acids production: multi-output optimization strategy. Biofuel Research Journal 11 (2016) 458-469. DOI: 10.18331/BRJ2016.3.3.5 


\begin{tabular}{|ll|}
\hline Abbreviations & \\
ANOVA & Analysis of variance \\
BC & Buffering capacity \\
CH$_{4}$ & Methane \\
CHP & Cumulative hydrogen production \\
CNG & Compressed natural gas \\
COD & Chemical oxygen demand \\
COD & COD removal \\
DEA & Data envelopment analysis \\
DOA & Degree of acidification \\
DOE & Design of experiments \\
DOF & Degree of freedom \\
DSW & Designed synthetic waste \\
H & Biohydrogen \\
HCE & Hydrogen conversion efficiency \\
MA & Methanogenic archaea \\
OA & Orthogonal array \\
OL & Organic load \\
SDR & Substrate degradation rate \\
SHY & Specific hydrogen yield \\
SI & Severity index \\
SRB & Sulphate reducing bacteria \\
THY & Theoretical hydrogen yield \\
VFA & Volatile fatty acids \\
VSS & Volatile suspended solids \\
\end{tabular}

\section{Introduction}

Anaerobic digestion process is a versatile process accompanied with unique advantages, e.g., high catalytic capacity and robustness, marking it suitable for multifunctional applications and for utilizing diverse feedstocks (Venkata Mohan, 2009; Menetrez, 2014; Trad et al., 2015). Acidogenesis, a stage of anaerobic digestion process, has been recently considered as potential platform for sustainable production of renewable bio-based products (Oyanedel et al., 2015; Venkata Mohan et al., 2016). In fact, acidogenesis is a branched cascade fermentation process that produces various bio-acids, bioalcohols, and bio-gases under specific regulatory activity of operational parameters. The major end products of regulated acidogenesis can be either high-energy molecules with fuel properties to provide clean energy or versatile precursor molecules for various chemical processes (Venkata Mohan et al., 2007; Mohanakrishna and Venkata Mohan, 2013; Singhania et al., 2013; Xia et al., 2015). Capability to produce a wide spectrum of biobased products viz., biohydrogen $\left(\mathrm{H}_{2}\right)$, biomethane $\left(\mathrm{CH}_{4}\right)$, short chain fatty acids (acetic acid, butyric acid, propionic acid, etc.), solvents (ethanol, butanol, propanol, and acetone), etc. is the prime benefit of the acidogenic process apart from utilization of various forms of feedstocks including waste streams (Thang et al., 2010; Venkata Mohan et al., 2016). The gaseous products of acidogenesis (i.e., $\mathrm{H}_{2}$ and $\mathrm{CH}_{4}$ ) are renewable and important energy carriers which can be used individually as well as in a blend. The individual limitations of $\mathrm{H}_{2}$ and $\mathrm{CH}_{4}$ could be overcome by blending them together in proportionate ratios to form biohythane (Liu et al., 2013; Elreedy et al., 2015; Pasupuleti and Venkata Mohan, 2015). Biohydrogen-enriched $\mathrm{CH}_{4}$ (i.e., biohythane) would be a good alternative to address the increasing demands for compressed natural gas (CNG) as engine fuel. Acidogenic fermentation of waste has attracted significant interest and is deemed to be one of the emerging areas in the domain of bio-economy (Nigam and Singh, 2011; Venkata Mohan et al., 2016).

Acidogenesis is very complex and the specific metabolic end-products differ depending on the operating parameters viz., nature and origin of inoculum, type and concentration of substrate, micronutrients, temperature, pH, etc. (Chiranjeevi et al., 2014; Pasupuleti et al., 2014; Pasupuleti and Venkata Mohan, 2015; Van Aarle et al., 2015). Inclusive understanding of the acidogenic process and the optimization of process parameters for the generation of specific product are significantly important, when waste is used as primary feedstock and mixed consortia as biocatalyst (Srikanth and Venkata Mohan, 2012 and 2014). To establish optimum conditions, numerous experiments have to be carried out with all the parametric combinations, which is practically difficult. Taguchi's design of experimental (DOE) methodology is a factorial based approach which helps to study a designed system with a set of independent variables (factors) over a specific region of interest (levels) (Venkata Mohan et al., 2009). This orthogonal array (OA) approach facilitates the study of interaction of a large number of variables spanned by the factors. The factors and their settings with a small number of experiments can lead to considerable saving of time and cost for process optimization (Venkata Mohan et al., 2009).

In this study, Taguchi DOE methodology was employed to enumerate the acidogenic fermentation process based on multiple metabolic end products viz., biohydrogen $\left(\mathrm{H}_{2}\right)$, biomethane $\left(\mathrm{CH}_{4}\right)$, biohythane, and volatile fatty acids (VFA), as well as wastewater treatment potentials, i.e., substrate degradation rate (SDR). In order to get a holistic view of the process critical factors of regulatory role on acidogenic metabolism i.e., $\mathrm{pH}$, substrate concentration, nitrates, sulfates, phosphates, bicarbonates, and molybdenum were taken into consideration for a detailed evaluation using an L18 OA of experiments.

\section{Experimental Details}

\subsection{DOE methodology}

DOE methodology based on Taguchi OA was employed to study the designed system with a set of independent variables (factors) over a specific region of interest (levels). Eight factors viz., biocatalyst, $\mathrm{pH}$ substrate concentration, nitrogen, sulfate, phosphate, molybdenum, temperature, and bicarbonate were selected with two/three levels to study their influence on the acidogenic products, i.e., biohydrogen $\left(\mathrm{H}_{2}\right)$, biohythane $\left(\mathrm{CH}_{4}\right)$, and short chain VFA (Table 1). Matrix experiments with an OA layout of L18 $\left(2^{1} \times 3^{7}\right)$ were designed and the diversity of factors (18 experimental sets with various combinations) was evaluated by crossing the OA (Table 2). The experimental data was processed with 'bigger is better' performance characteristics (Qualitek 4 software, Nutek Inc.).

Table 1.

Selected factors and their assigned levels.

\begin{tabular}{cllll}
\hline $\begin{array}{l}\text { Severity } \\
\text { index }\end{array}$ & Factors & Level 1 & Level 2 & Level 3 \\
\hline 1 & Biocatalyst & Untreated & Pretreated & - \\
2 & $\mathrm{pH}$ & 6 & 7 & 8.5 \\
3 & Organic load (g COD /L) & 3 & 5 & 10 \\
4 & Sulphate (mg/L) & 0 & 250 & 1000 \\
5 & Nitrate (mg/L) & 0 & 300 & 600 \\
6 & Phosphate (mg/L) & 0 & 500 & 1000 \\
7 & Molybdenum (mg/L) & 0 & 10 & 25 \\
8 & Bicarbonate (mg/L) & 0 & 500 & 1000 \\
\hline
\end{tabular}

\subsection{Acidogenic digestion}

Anaerobic sludge samples from a full-scale anaerobic reactor treating composite wastewater were used as parent inoculums. The parent culture after collection was sieved to separate coarse materials using nylon filter and the resulted thick sludge was subjected to acid-shock pretreatment by adjusting the $\mathrm{pH}$ to 3 using $\mathrm{HNO}_{3}(0.1 \mathrm{~N})$ for a period of $24 \mathrm{~h}$ under anaerobic conditions (Sarkar et al., 2013). Designed synthetic wastewater (DSW: $\mathrm{NH}_{4} \mathrm{Cl}, 0.5 \mathrm{~g} / \mathrm{L} ; \mathrm{KH}_{2} \mathrm{PO}_{4}, 0.25 \mathrm{~g} / \mathrm{L} ; \mathrm{K}_{2} \mathrm{HPO}_{4}, 0.25 \mathrm{~g} / \mathrm{L} ; \mathrm{MgCl}_{2} 0.3$ $\mathrm{g} / \mathrm{L} ; \mathrm{CoCl}_{2}, 25 \mathrm{mg} / \mathrm{L} ; \mathrm{ZnCl}_{2}, 11.5 \mathrm{mg} / \mathrm{L} ; \mathrm{CuCl}_{2}, 10.5 \mathrm{mg} / \mathrm{L} ; \mathrm{CaCl}_{2}, 5$ $\mathrm{mg} / \mathrm{L} ; \mathrm{MnCl}_{2}, 15 \mathrm{mg} / \mathrm{L} ; \mathrm{NiSO}_{4}, 16 \mathrm{mg} / \mathrm{L} ; \mathrm{FeCl}_{3}, 25 \mathrm{mg} / \mathrm{L}$ ) was used as source of nutrients and the parameters (including glucose) were varied according to the experimental design requirement (Table 1). Designed experimental variations (No. 18) were carried out in $250 \mathrm{ml}$ flaks in batch mode (working volume of $110 \mathrm{ml}$ ) at ambient temperature $\left(30 \pm 2{ }^{\circ} \mathrm{C}\right)$ using a magnetic shaker (100 rpm). The biocatalyst $(20 \mathrm{ml}$; 
Table 2.

Orthogonal array [L18] of the designed experiments and the output parameters of the acidogenic process.

\begin{tabular}{|c|c|c|c|c|c|c|c|c|c|c|c|c|c|c|c|}
\hline \multirow{2}{*}{$\begin{array}{l}\text { Experiment } \\
\text { No. }\end{array}$} & \multicolumn{8}{|c|}{ Factors } & \multirow{2}{*}{ CHP (L) } & \multirow{2}{*}{ HCE $(\%)$} & \multirow{2}{*}{$\operatorname{COD}_{\mathrm{R}}(\%)$} & \multirow{2}{*}{ VFA $(\mathrm{mg} / \mathrm{L})$} & \multirow{2}{*}{ DOA $(\%)$} & \multirow{2}{*}{ Biohythane (L) } & \multirow{2}{*}{$\mathbf{H}_{2} / \mathbf{H}_{2}+\mathbf{C H}_{4}$} \\
\hline & 1 & 2 & 3 & 4 & 5 & 6 & 7 & 8 & & & & & & & \\
\hline 1 & 1 & 1 & 1 & 1 & 1 & 1 & 1 & 1 & 0.66 & 79.9 & 44 & 1119 & 44 & 4.98 & 0.13 \\
\hline 2 & 1 & 1 & 2 & 2 & 2 & 2 & 2 & 2 & 0.38 & 16.5 & 55 & 1163 & 31 & 3.38 & 0.11 \\
\hline 3 & 1 & 1 & 3 & 3 & 3 & 3 & 3 & 3 & 0.61 & 9.8 & 49 & 2074 & 26 & 4.11 & 0.15 \\
\hline 4 & 1 & 2 & 1 & 1 & 2 & 2 & 3 & 3 & 0.66 & 39.7 & 20 & 892 & 36 & 3.66 & 0.18 \\
\hline 5 & 1 & 2 & 2 & 2 & 3 & 3 & 1 & 1 & 0.51 & 17.7 & 44 & 1619 & 39 & 4.31 & 0.12 \\
\hline 6 & 1 & 2 & 3 & 3 & 1 & 1 & 2 & 2 & 2.69 & 44.2 & 42 & 3220 & 40 & 7.89 & 0.34 \\
\hline 7 & 1 & 3 & 1 & 2 & 1 & 3 & 2 & 3 & 0.81 & 70.1 & 53 & 915 & 40 & 2.81 & 0.29 \\
\hline 8 & 1 & 3 & 2 & 3 & 2 & 1 & 3 & 1 & 0.90 & 34.8 & 50 & 1165 & 30 & 3.2 & 0.28 \\
\hline 9 & 1 & 3 & 3 & 1 & 3 & 2 & 1 & 2 & 3.15 & 55.8 & 37 & 3309 & 41 & 6.85 & 0.46 \\
\hline 10 & 2 & 1 & 1 & 3 & 3 & 2 & 2 & 1 & 0.88 & 70.6 & 39 & 995 & 42 & 0.94 & 0.94 \\
\hline 11 & 2 & 1 & 2 & 1 & 1 & 3 & 3 & 2 & 1.63 & 63.0 & 37 & 2031 & 53 & 1.73 & 0.94 \\
\hline 12 & 2 & 1 & 3 & 2 & 2 & 1 & 1 & 3 & 3.97 & 48.0 & 31 & 4303 & 51 & 4.11 & 0.97 \\
\hline 13 & 2 & 2 & 1 & 2 & 3 & 1 & 3 & 2 & 0.92 & 76.6 & 46 & 1132 & 50 & 0.97 & 0.95 \\
\hline 14 & 2 & 2 & 2 & 3 & 1 & 2 & 1 & 3 & 1.63 & 63.0 & 30 & 1402 & 38 & 1.69 & 0.96 \\
\hline 15 & 2 & 2 & 3 & 1 & 2 & 3 & 2 & 1 & 1.22 & 6.4 & 32 & 3425 & 41 & 1.49 & 0.82 \\
\hline 16 & 2 & 3 & 1 & 3 & 2 & 3 & 1 & 2 & 0.76 & 73.3 & 20 & 1419 & 62 & 0.87 & 0.87 \\
\hline 17 & 2 & 3 & 2 & 1 & 3 & 1 & 2 & 3 & 1.15 & 45.9 & 51 & 2002 & 51 & 1.20 & 0.95 \\
\hline 18 & 2 & 3 & 3 & 2 & 1 & 2 & 3 & 1 & 1.79 & 21.0 & 30 & 3035 & 37 & 2.08 & 0.86 \\
\hline
\end{tabular}

untreated/pretreated inoculums according to the design) was added through the feed (i.e., $100 \mathrm{ml}$ of DSW) after adjusting to the required $\mathrm{pH}$ (i.e., 6.0, 7.0, and 8.0) with $1 \mathrm{~N} \mathrm{NaOH} / 1 \mathrm{~N} \mathrm{HCl}$. Nitrate, carbonate, phosphate, sulphate and molybdenum were sourced from $\mathrm{NaNO}_{3}, \mathrm{NaHCO}_{3}, \mathrm{NaH}_{2} \mathrm{PO}_{4}, \mathrm{Na}_{2} \mathrm{SO}_{4}$, and $\mathrm{Na}_{2} \mathrm{MoO}_{4}$, respectively, and the required concentration was supplemented through DSW. For the validation of the DOE output, acidogenic experiments were further performed in a semi-pilot scale hybrid bioreactor with a total volume/working volume $40 \mathrm{~L} / 35 \mathrm{~L}$ with a gas holding capacity of $5 \mathrm{~L}$. The bioreactor was designed to operate in up flow mode (L/D ratio-2) and was filled with coir pith as fixed bed packing material to support the formation of biofilm.

\subsection{Analytical methods}

Biohydrogen evolved in the headspace of the reactors during batch experiments was estimated using a microprocessor based pre-calibrated $\mathrm{H}_{2}$ sensor (ATMI GmBH Inc.). Biogas composition was analyzed through gas chromatography (GC; NUCON 5765) using a thermal conductivity detector (TCD; $1 / 8^{\prime \prime} \times 2 \mathrm{~m}$ Heysep Q column) and argon as carrier gas. The injector and detector were maintained at $60{ }^{\circ} \mathrm{C}$ each and the oven was operated at 40 ${ }^{\circ} \mathrm{C}$ isothermally. The performance of acidogenic experiments was also assessed by analyzing chemical oxygen demand (COD; closed refluxing titrimetric method), VFA, and pH (APHA, 1998). Carboxylate acid (acetate, propionate, butyrate, valarate, etc.) composition was analyzed using a HPLC (Shimadzu LC10A) equipped with a UV-VIS detector $(210 \mathrm{~nm})$ and a C18 reverse phase column $(250 \times 4.6 \mathrm{~mm}$ dia; $5 \mu \mathrm{m}$ particle size, $0.5 \mathrm{~mL} / \mathrm{h} ; 210$ $\mathrm{nm})$. Acetonitrile was used as mobile phase $\left(40 \%\right.$ in $1 \mathrm{mN} \mathrm{H}_{2} \mathrm{SO}_{4} ; \mathrm{pH}, 2.5-$ $3.0)$ and $20 \mu \mathrm{l}$ of the filtered sample $(0.22 \mu \mathrm{m}$ porosity) was injected and monitored against acids standards (SUPELCO).

\subsection{Data analysis}

The experimental data obtained was processed employing Qualitek-4 (Nutek Inc.) software to evaluate the influence of individual factors, multiple interactions of the selected factors on output parameters, determination of optimum conditions, and process performance at the obtained optimum conditions. Software for optimization was operated at 'bigger is better' performance characteristics for all the cases. Hydrogen conversion efficiency (HCE) represents the amount of COD present in wastewater converted to $\mathrm{H}_{2}$. HCE was calculated based on the Equation 1 relating cumulative $\mathrm{H}_{2}$ production (CHP, L), organic load of the substrate (OL, g COD/L), substrate removal efficiency $\left(\mathrm{COD}_{\mathrm{R}}, \%\right)$, and wastewater feed volume $(\mathrm{V}, \mathrm{L})$.

$H C E(\%)=\frac{C H P * 10000}{O L * C O D_{R} * V * T H Y}$
$1 \mathrm{~kg}$ of COD (wastewater) can produce $468.83 \mathrm{~L}$ of $\mathrm{H}_{2}$ (based on acetate pathway) known as theoretical hydrogen yield (THY) (Pasupuleti et al., 2014). Degree of acidification (DOA) represents the extent of acidification achieved due to the production of carboxylic acids in relation to substrate (as COD) degradation (Eq. 2) (Sarkar et al., 2016).

$\operatorname{DOA}(\%)=\frac{s_{f}}{s_{i}} \times 100$

Where, $\mathrm{S}_{\mathrm{i}}$ represents the initial COD concentration $(\mathrm{mg} / \mathrm{L})$ and $\mathrm{S}_{\mathrm{f}}$ is net VFA concentration (final-initial) expressed as theoretical equivalents of COD (in mg/L, $\mathrm{H}_{\mathrm{Ac}}, 1.066 ; \mathrm{H}_{\mathrm{Pr},}, 1.512 ; \mathrm{H}_{\mathrm{Bu}}, 1.816$ ). Buffering capacity $(\beta)$ was estimated based on the acid-base titrations employing auto-titrator (Mettler Toledo). $\beta$ was calculated using the Equation 3, where $\mathrm{C}$ is the concentration of acid or base (mol), $\mathrm{V}_{\mathrm{s}}$ is the volume of sample $(\mathrm{mL}), \mathrm{m}$ is the slope of tangent on curve.

$\beta(\mathrm{mol})=\frac{C}{V_{s} \times m}$

\section{Results and discussion}

\subsection{Individual factors influence}

\subsubsection{Biohydrogen}

Table 3 tabulates the main effects of the selected factors on CHP.

Table 3.

Main effects of the selected factors on cumulative hydrogen production (CHP).

\begin{tabular}{llllll}
\hline $\begin{array}{l}\text { Severity } \\
\text { index }\end{array}$ & Factors & Level 1 & Level 2 & Level 3 & L2-L1 \\
\hline 1 & Bicarbonates & 1.951 & 3.129 & 2.894 & 1.177 \\
2 & Biocatalyst & 2.268 & 3.084 & - & 0.78 \\
3 & Organic Load & 1.536 & 2.036 & 4.403 & 0.5 \\
4 & pH & 2.781 & 2.749 & 2.444 & -0.033 \\
5 & Sulphates & 2.67 & 2.499 & 2.806 & -0.171 \\
6 & Nitrates & 3.023 & 2.588 & 2.364 & -0.436 \\
7 & Phosphates & 3.369 & 2.783 & 1.822 & -0.587 \\
8 & Molybdenum & 3.503 & 2.338 & 2.134 & -1.166 \\
\hline
\end{tabular}



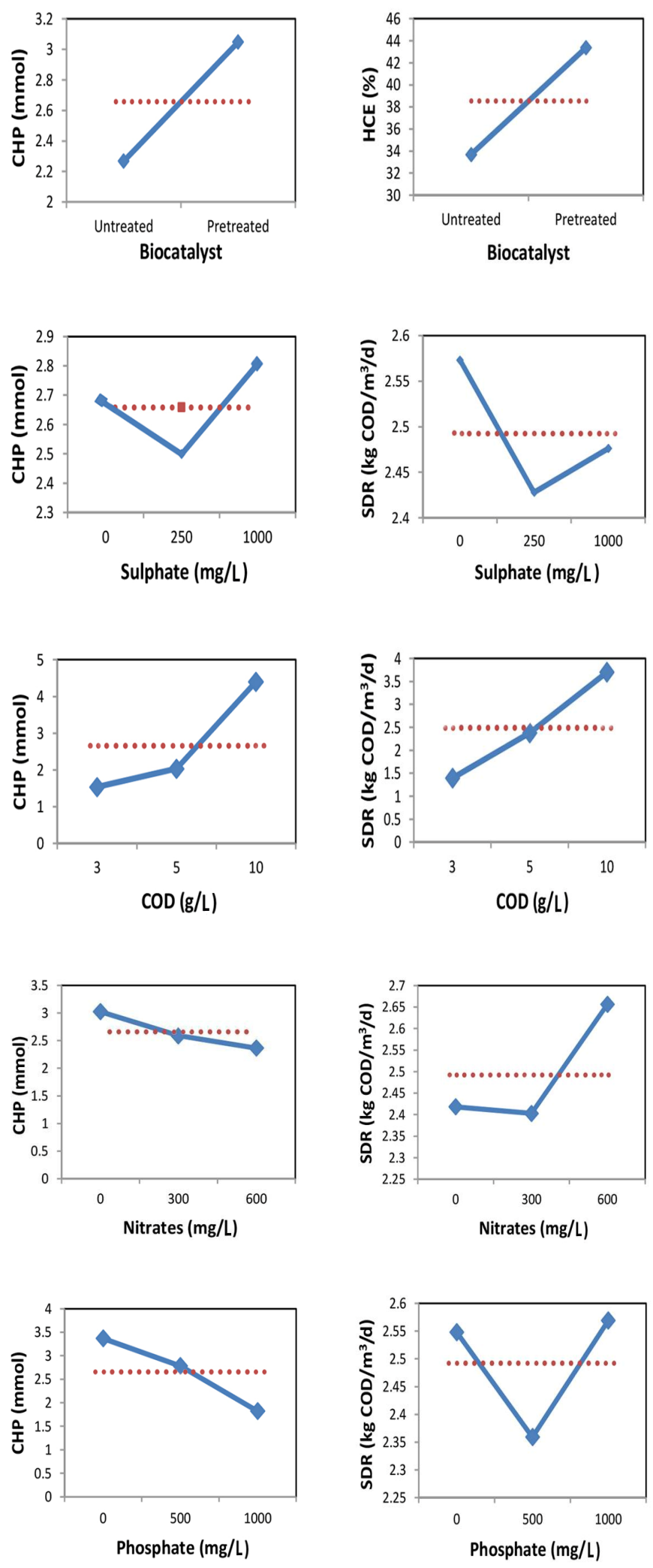
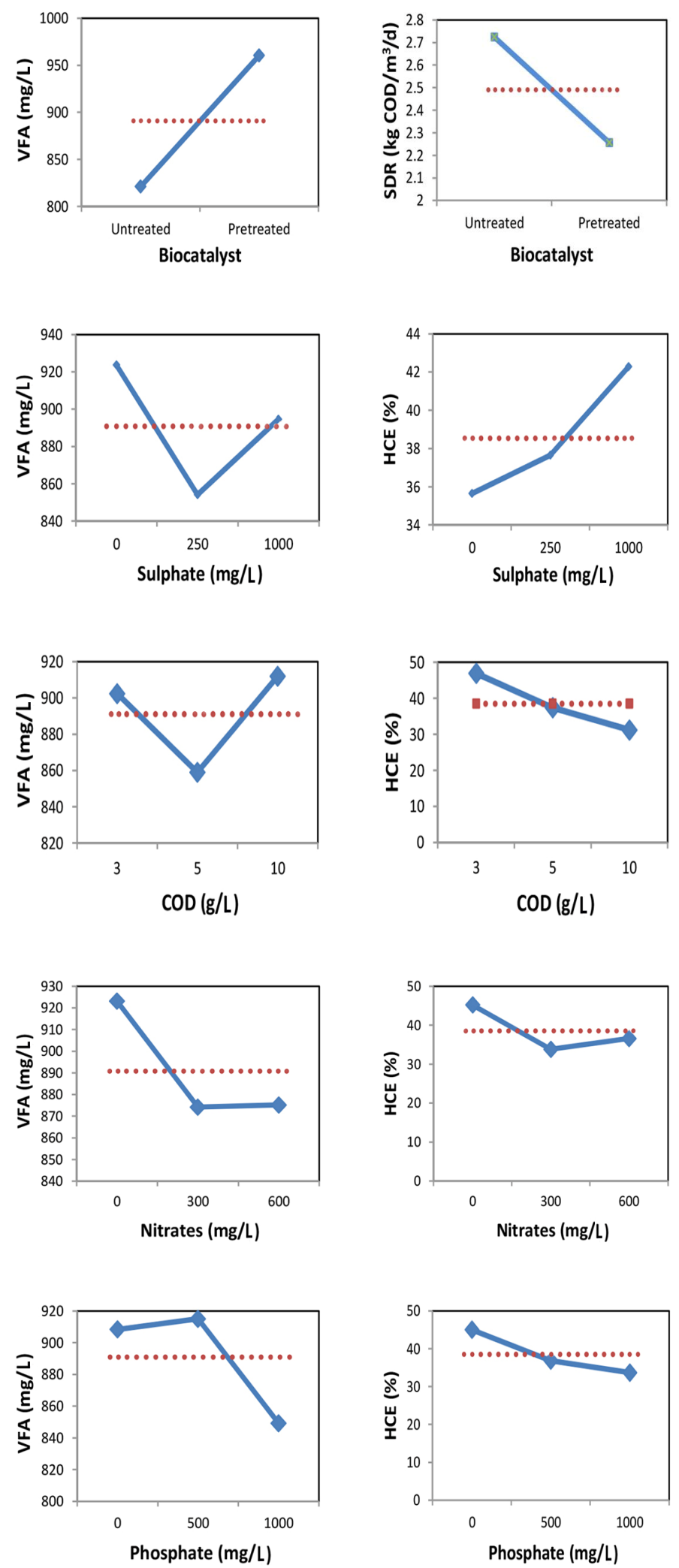

Fig.1. The effects of the investigated factors at different levels on various performance parameters 

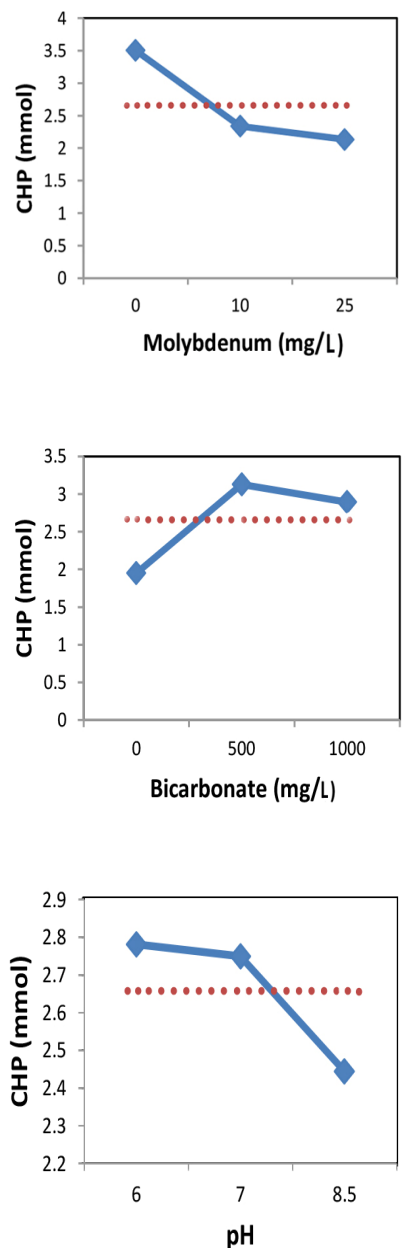
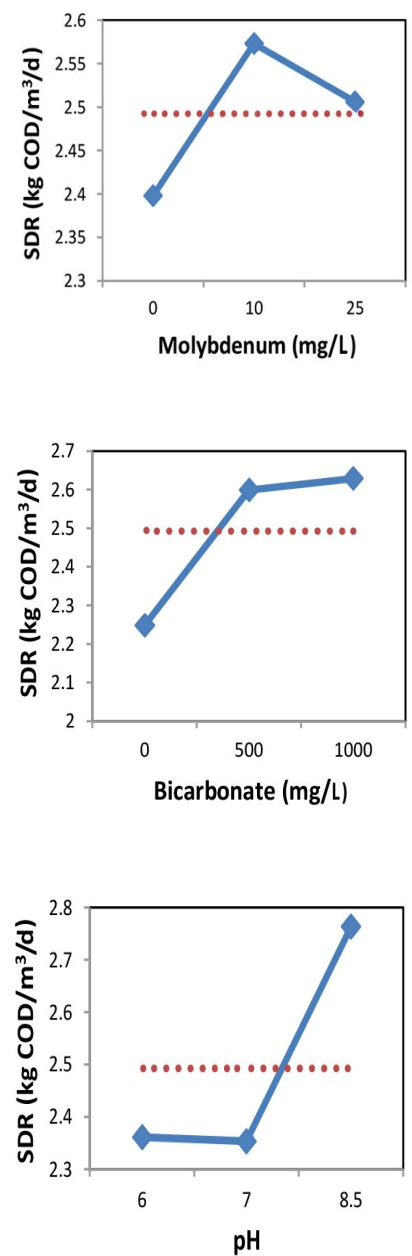
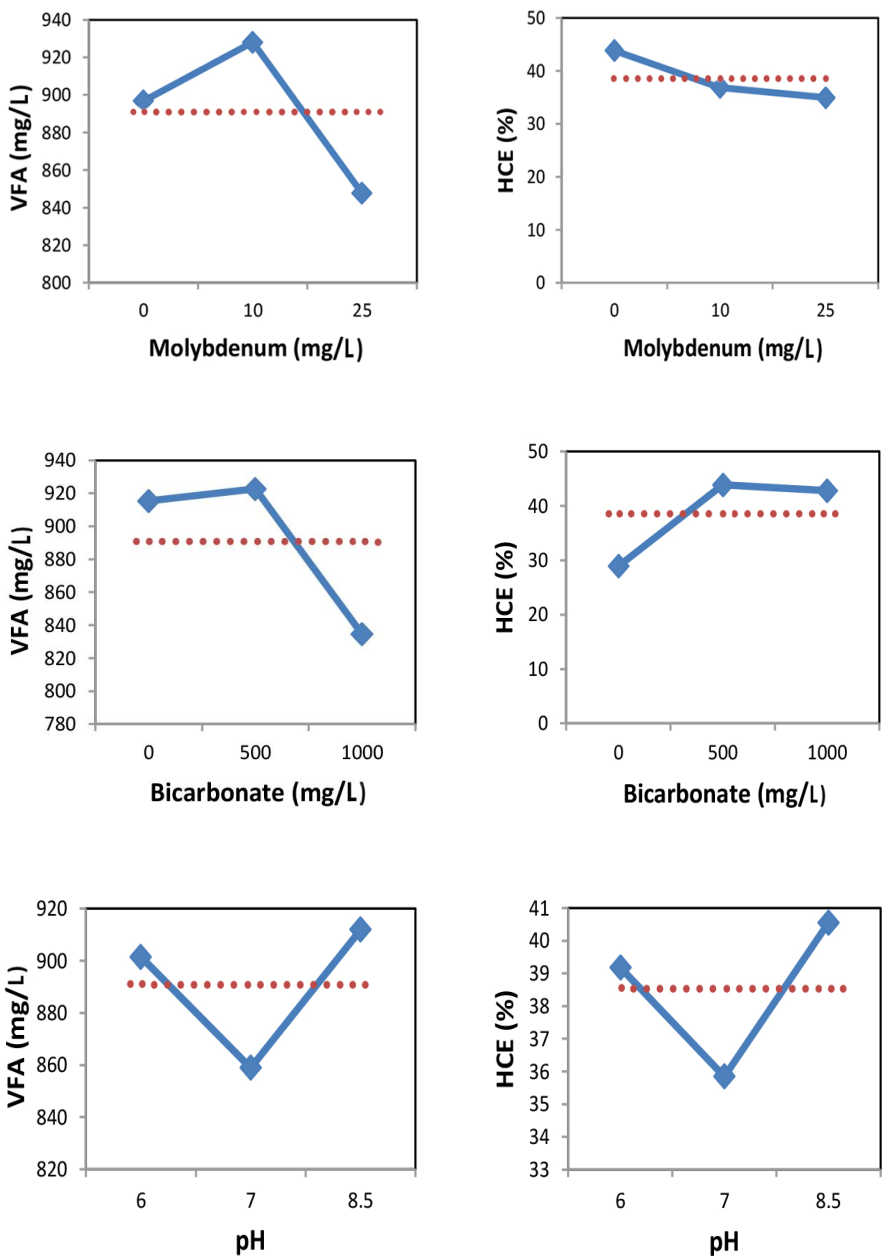

Fig.1 (Continued). The effects of the investigated factors at different levels on various performance parameters

Figure 1 presents the influence of individual factors on $\mathrm{H}_{2}$ production. Individually, at the level stage, OL at L3 showed higher CHP $(4.40 \mathrm{~L})$ followed by molybdenum at L1 $(3.50 \mathrm{~L})$, phosphates at $\mathrm{L} 1(3.37 \mathrm{~L})$, bicarbonate at $\mathrm{L} 2(3.12 \mathrm{~L}$, and pretreated biocatalyst at $\mathrm{L} 2(3.08 \mathrm{~L})$ with the lowest CHP observed with OL at its lowest concentration (i.e., L1 at $1.54 \mathrm{~L}$ ). The difference between values at levels 2 and level 1 (L2-L1) of each factor indicates the relative influence of the factors. The negative value is ignored in assessing the main effect as the placement order of levels assigns either positive or negative values. By studying the main effects of each of the factor, the general trend of influence of factors towards the process output parameters could be characterized. The relative influence of the selected factors on the $\mathrm{H}_{2}$ production was as follows: bicarbonates > molybdenum > biocatalyst > phosphates $>\mathrm{COD}>$ nitrates $>$ sulphates $>\mathrm{pH}$. Specific to $\mathrm{H}_{2}$ production, bicarbonate and molybdenum followed by biocatalyst pretreatment, phosphate, OL, nitrates, and sulphates showed significant influences. The first eight experimental sets with CHP values greater than 1.0 $\mathrm{L}$ depicted distinct variations among the conditions to specific process input parameters. Highest CHP (3.97 L) was achieved with the experiment No. 12 followed by No. 9 and 6 (Fig. 2). Specific to the biocatalyst selection, pretreatment facilitated the elimination of methanogenesis and, therefore, higher $\mathrm{H}_{2}$ production could be achieved. Shifting or regulating the metabolic pathway towards acidogenesis and inhibition of methanogenesis facilitate higher $\mathrm{H}_{2}$ yields (Venkata Mohan et al., 2008; Sarkar et al., 2013).

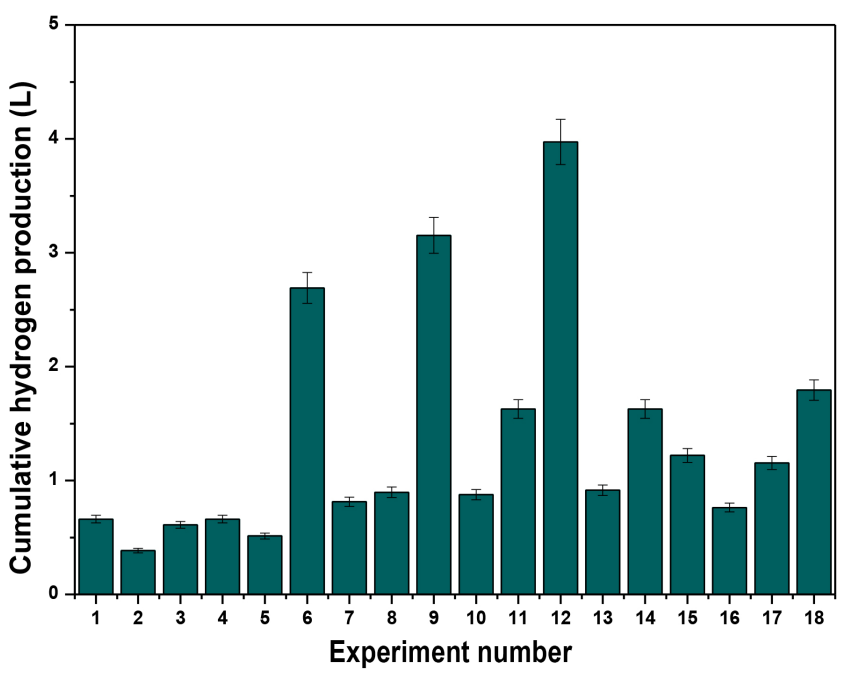

Fig.2. Cumulative hydrogen production (CHP) at different experimental variations. 
Physiological differences between acidogenic bacteria (AB) and methanogenic archaea (MA) form the main basis for the preparation of biocatalyst for acidogenic fermentation (Goud and Venkata Mohan, $2012 \mathrm{a}$, b; Wang et al., 2011). Except two experimental conditions (i.e., No. 9 and 6), all the other sets showed feasibility to operate with the pretreated consortia (L2) under the first eight conditions.

Experiment No 9 (CHP; $3.15 \mathrm{~L}$ ) was operated at $\mathrm{pH} 8.5$ (L3) with high COD load (L3) and in the presence of nitrates (L3) and phosphates (L2). The higher $\mathrm{H}_{2}$ production observed under this condition might be attributed to the operation at basic redox condition, which inhibits the MA activity. The operating $\mathrm{pH}$ influences the function of $\mathrm{H}_{2}$-producing bacteria and also the hydrogenase activity (Khanal et al., 2004; Venkata Mohan et al., 2007; Mohanakrishna et al., 2011). Bicarbonate showed a significant effect on the $\mathrm{H}_{2}$ production at selected levels. It acted as a natural $\mathrm{pH}$ buffer, and contributed to the alkalinity. Experiments carried out with higher concentration of $\mathrm{HCO}_{3}{ }^{-}(1 \mathrm{~g} / \mathrm{L})$ showed highest buffering capacity (BC) (Fig. 3 ). Beyond its function as a buffer, $\mathrm{HCO}_{3}{ }^{-}$also serves as an electron acceptor. At neutral $\mathrm{pH}$, hydrogenotrophic methanogens consumes $\mathrm{HCO}_{3}^{-}$and $\mathrm{H}_{2}$ to generate $\mathrm{CH}_{4}$. This was observed in experiments particularly operated with untreated inoculum.

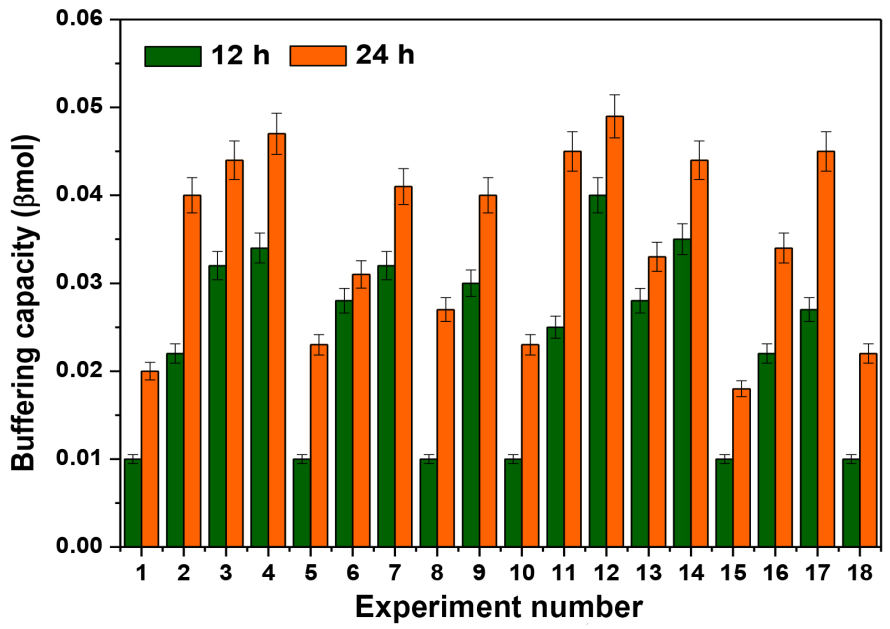

Fig.3. Buffering capacity analyzed at 12 and $24 \mathrm{~h}$ of operation for different experimental conditions.

Experiment No. 6 operated with sulphate concentration of $1 \mathrm{~g} / \mathrm{L}$ (L3) at neutral redox condition (L1) and with higher COD load (L3) and molybdenum concentration (L2; $10 \mathrm{mg} / \mathrm{L}$ ) also showed a rather high $\mathrm{CHP}$ (2.69 L). The high $\mathrm{H}_{2}$ production observed under this condition might be due the presence of sulphate at relatively higher concentration. Sulphate enhances the hydrolysis and acidogenesis of particular organics (Rodríguez et al., 2005). However, high sulphate concentration diverts the bacterial pathway towards sulfate reducing bacteria (SRB) where initially sulfate is reduced to sulfite and then to sulfide. In fact, $\mathrm{SRBs}$ compete with $\mathrm{H}_{2}$-producing bacteria for the same electron donors resulting in lower hydrogen production (Chen et al., 2008; Hwang et al., 2009). Despite the application of untreated biocatalyst, experiment No. 6 showed an acceptable CHP $(2.69 \mathrm{~L})$ which might be attributed to the presence of molybdenum $(10 \mathrm{mg} / \mathrm{l})$. Molybdenum plays a very specific role in the activity of dehydrogenase which contains subunits requiring molybdenum as cofactor to function (Popov and Lamzin, 1994; McDowall et al., 2014)

Carbon load (i.e., COD) also showed marked influence on $\mathrm{H}_{2}$ production, wherein the first four experimental sets (i.e., 6, 9, 12, and 18) with higher $\mathrm{H}_{2}$ production showed operation at L3. OL has direct correlation with the metabolic activity and hence, with the $\mathrm{H}_{2}$ production (Ginkel et al., 2005; Mohanakrishna et al., 2011; Sarkar et al., 2016). Appropriate levels of nitrogen and phosphate are beneficial to the growth of acidogenic bacteria (Wang et al., 2009). Appropriate range of phosphate concentration could increase the ability of $\mathrm{H}_{2}$ producing bacteria, but concentrations at much higher levels could lead to decreased productivity (Lin and Lay, 2004; Wang et al., 2009 ; Liu et al., 2015). An appropriate $\mathrm{C} / \mathrm{N}$ and $\mathrm{C} / \mathrm{P}$ are fundamental for any biological processes to function metabolically effective. $\mathrm{C} / \mathrm{N}$ and $\mathrm{C} / \mathrm{P}$ ratios in the designed experiment varied in the range of 0-33 and 0-20, respectively. Inappropriate concentration of $\mathrm{C} / \mathrm{N}$ ratios may inhibit biological processes (Kim et al., 2006). Specifically lower C/N ratio lead to the accumulation of ammonia. However, the optimum $\mathrm{C} / \mathrm{N}$ ratio determined herein was significantly different from the literature (Lin and Lay, 2004).

Table 4.

Main effects of the selected factors on substrate degradation rate (SDR).

\begin{tabular}{llllll}
\hline $\begin{array}{l}\text { Severity } \\
\text { index }\end{array}$ & Factors & Level 1 & Level 2 & Level 3 & L2-L1 \\
\hline 1 & Organic Load & 1.394 & 2.379 & 3.703 & 0.985 \\
2 & Bicarbonates & 2.248 & 2.599 & 2.629 & 0.35 \\
3 & Molybdenum & 2.398 & 2.573 & 2.506 & 0.174 \\
4 & pH & 2.361 & 2.353 & 2.763 & -0.009 \\
5 & Nitrates & 2.418 & 2.403 & 2.656 & -0.016 \\
6 & Sulphates & 2.573 & 2.428 & 2.476 & -0.146 \\
7 & Phosphates & 2.548 & 2.359 & 2.569 & -0.19 \\
8 & Biocatalyst & 2.727 & 2.257 & - & -0.47 \\
\hline
\end{tabular}

3.1.2. Substrate degradation rate (SDR) and hydrogen conversion efficiency (HCE)

The factors which influence on SDR and HCE are diverse. SDR is majorly influenced by carbon load, biocatalyst, bicarbonate, molybdenum, phosphates, sulphates, nitrates, and $\mathrm{pH}$. Higher SDR values were observed at the highest and lowest organic loads, i.e., $\mathrm{L} 3\left(3.7 \mathrm{~kg} \mathrm{COD} / \mathrm{m}^{3} /\right.$ day) and L1 $\left(1.39 \mathrm{~kg} \mathrm{COD} / \mathrm{m}^{3} / \mathrm{d}\right)$, respectively (Table 4). Specific to substrate degradation, untreated biocatalyst showed a positive influence due to its feasibility to extend the process until methanogenesis.

In the case of HCE, bicarbonate showed a significant influence followed by nitrate, biocatalyst, carbon load, phosphate, molybdenum, and $\mathrm{pH}$. HCE results revealed that $\mathrm{H}_{2}$ production was proportional to substrate degradation. Higher HCE was observed with lower organic load $(\mathrm{L} 1 ; 46.97 \%)$ in the absence of nitrates $(\mathrm{L} 1 ; 45.19 \%)$ and phosphates $(\mathrm{L} 1$; $45.03 \%)$ followed by biocarbonate $(43.85 \%$; L2) (Table 5). Pretreated biocatalyst yielded a higher performance (L2; 43.37\%) compared with the untreated biocatalyst $(\mathrm{L} 1 ; 33.69 \%)$. Among the first five experimental conditions showing higher HCE values $(>70 \%)$, three were related to using pretreated consortia and all five showed optimum operation at lower organic load (L1).

Table 5.

Main effects of the selected factors on hydrogen conversion efficiency (HCE).

\begin{tabular}{llllll}
\hline $\begin{array}{l}\text { Severity } \\
\text { index }\end{array}$ & Factors & Level 1 & Level 2 & Level 3 & L2-L1 \\
\hline 1 & Bicarbonates & 28.916 & 43.85 & 42.816 & 14.934 \\
2 & Biocatalyst & 33.688 & 43.366 & - & 9.677 \\
3 & Sulphates & 35.649 & 37.65 & 42.283 & 2 \\
4 & pH & 39.183 & 35.849 & 40.594 & -3.335 \\
5 & Molybdenum & 43.8 & 36.866 & 34.916 & -6.934 \\
6 & Phosphates & 45.033 & 36.85 & 33.7 & -8.183 \\
7 & Organic Load & 46.966 & 37.383 & 31.233 & -9.583 \\
8 & Nitrates & 45.199 & 33.799 & 36.583 & -11.4 \\
\hline
\end{tabular}


For instance, experiment No. 1 was specifically operated at acidic $\mathrm{pH}(6.0)$ and low COD load (L1) without any of nutrients or trace components and led to an HCE value of $79.9 \%$. It should be noted that operation under acidophilic conditions restricts the function of MA, which could in turn result in a reasonably high HCE. Moreover, experiment No.7 was operated under basic redox condition $(\mathrm{pH}, 8.5)$ (which has a negative effect on the activity and function of MA) and led to an HCE value of $70.1 \%$. Therefore, in spite of using untreated biocatalyst, operation at $\mathrm{pH}$ range inhibitory to MA resulted in acceptable $\mathrm{H}_{2}$ production. Contrary to the CHP, higher HCE value was observed at low COD load (L1; $3 \mathrm{~g} / \mathrm{L})$. This might be due to the losses during metabolic conversion, wherein, higher carbon load facilitated parallel biochemical reaction to manifest other process. Higher carbon load operation also increases the VFA accumulation in the systems and influence the system redox condition, which will have negative effect on the conversion efficiency.

\subsubsection{Biohythane production}

Unsuppressed methanogens in the untreated inoculum facilitated the formation of $\mathrm{CH}_{4}$ along with $\mathrm{H}_{2}$. The first nine experiments (i.e., experiments 1-9) operated with untreated inoculum, specifically depicted higher $\mathrm{CH}_{4}$ production varying from 2.01 (experiment No. 7) to 5.21 (experiment No. 6). In these experiments, $\mathrm{H}_{2}$ production was relatively low and biohythane varied from 2.81 to $7.89 \mathrm{~L}$ (Fig. 4). Ratio of $\mathrm{H}_{2} / \mathrm{H}_{2}+\mathrm{CH}_{4}\left(\mathrm{CO}_{2}\right.$ was excluded) varied between 0.1 (experiment No. 2) to 0.46 (experiment No. 9). It has been reported that a proportionate mixture of $\mathrm{H}_{2}$ and $\mathrm{CH}_{4}$ as biohythane (i.e., 0.1 to 0.3) can be beneficially used (Fulton et al., 2010; Pasupuleti and Venkata Mohan, 2015; Oyanedel et al., 2015). Experiment No. 6 which illustrated higher productivity of combined biogas was operated at neutral $\mathrm{pH}$ at a higher organic load. Experiments 10 to 18 operated with pretreated biocatalyst showed relatively lower $\mathrm{CH}_{4}$ values $(0.05$ to $0.29 \mathrm{~L})$ than $\mathrm{H}_{2}(0.76$ to $3.97 \mathrm{~L})$ wherein, biohythane production varied from 0.87 to $4.11 \mathrm{~L}$ (Fig. 4). In these experiments, the ratio of $\mathrm{H}_{2} / \mathrm{H}_{2}+\mathrm{CH}_{4}$ varied from 0.82 to 0.97 . Experiment No. 12 which illustrated higher biohythane production was operated under acidic $\mathrm{pH}$ at a higher organic load. It is worth highlighting that biohythane would be a good alternate to $\mathrm{CNG}$

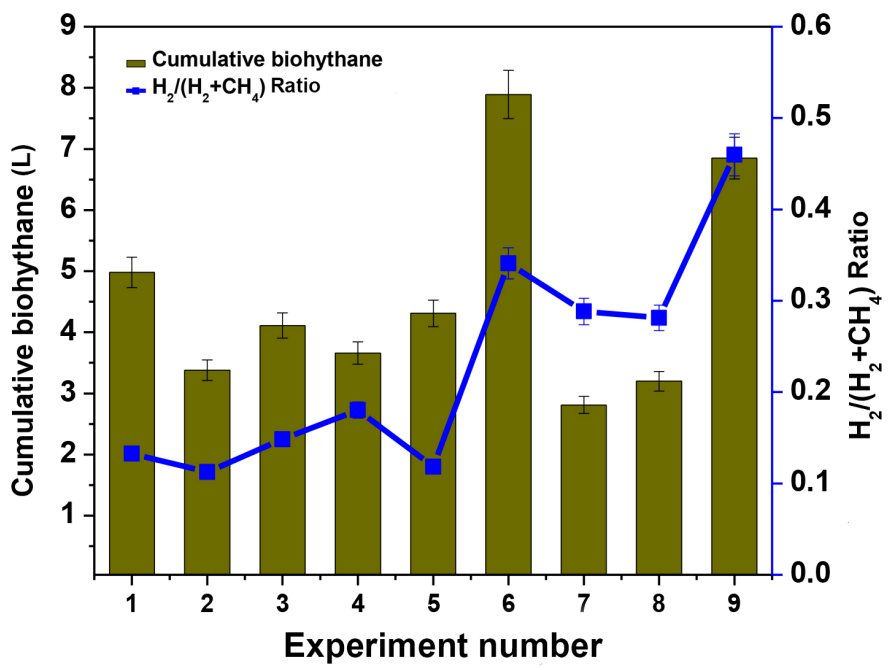

Fig.4. Composition of $\mathrm{H}_{2}$ in biohythane gas with respect to different experimental conditions.

\subsubsection{Volatile fatty acids (VFA) production}

The production of short chain VFAs (carboxylic acids) generally indicates the progress of anaerobic process. Specific to VFA production, organic load and nature of biocatalyst showed a strong influence followed by phosphates, molybdenum, bicarbonates, nitrates, sulfates, and $\mathrm{pH}$. Individually, at the level stage, higher carbon load at L3 level $(3274 \mathrm{mg} / \mathrm{L})$ and pretreatment of biocatalyst (L2; $2208 \mathrm{mg} / \mathrm{L}$ ) led to higher VFA synthesis (Table 6). Pretreatment of the parent culture (consortia) documented an important role in the selective enrichment of $\mathrm{AB}$ to regulate metabolism towards short chain
Table 6.

Main effects of the selected factors on VFA production.

\begin{tabular}{llcccc}
\hline $\begin{array}{l}\text { Severity } \\
\text { index }\end{array}$ & Factors & Level 1 & Level 2 & Level 3 & L2-L1 \\
\hline 1 & Biocatalyst & 1779 & 2208 & - & 427 \\
2 & Input pH & 1992 & 1985 & 2003 & -7.33 \\
3 & Organic load & 1092 & 1613 & 3274 & 520 \\
4 & Sulphates & 2159 & 2060 & 1760 & -99 \\
5 & Nitrates & 1985 & 2092 & 1903 & 105 \\
6 & Phosphates & 2188 & 1829 & 1963 & -360 \\
7 & Molybdenum & 2226 & 1986 & 1768 & -240 \\
8 & Bicarbonates & 1924 & 2098 & 1959 & 173 \\
\hline
\end{tabular}

carboxylic acids synthesis (Venkata Mohan et al., 2008; Sarkar et al., 2016). Specifically, the absence of molybdenum (L1; $2226 \mathrm{mg} / \mathrm{L}$ ), phosphates (L1, $2188 \mathrm{mg} / \mathrm{L})$, and sulfates (L1; $2159 \mathrm{mg} / \mathrm{L})$ showed higher VFA productivity. On the contrary, nitrate concentration at L2 level (2092 L) showed a relatively higher production. Among the 18 experimental variations studied, experiment No. 12 (4.3 g VFA/L), 15 (3.4 g VFA/L), 9 (3.3 g VFA/L), 6 (3.2 g VFA/L), and 18 (3.0 g VFA/L) resulted in relatively higher VFA production rates (i.e., $>3 \mathrm{~g}$ VFA/L) associated with higher fraction of acetic acid followed by butyric acid. Interestingly, all these experimental sets were operated at higher organic load (L3; $10 \mathrm{~g}$ $\mathrm{COD} / \mathrm{L}$ ) indicating the requirement for more carbon towards acidogenic synthesis. Pretreated biocatalyst showed an influence on acid synthesis (experiment No. 12, 15, and 18) at $\mathrm{pH} 5$ and 7. Untreated biocatalyst specifically functioned towards acid production, i.e., in experiment No. 9 $(\mathrm{pH}, 8.5)$ and experiment No. 6 (sulfates, $1 \mathrm{~g} / \mathrm{L}$ ).

Fatty acid profiles showed higher fraction of acetic acid followed by butyric acid and low concentrations of propionic acid (Fig. 5).

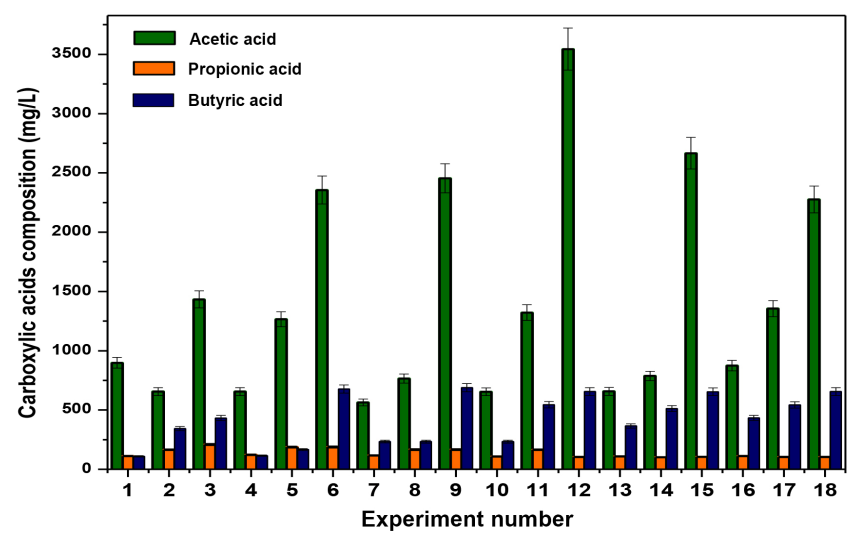

Fig.5. Carboxylic acid (VFA) composition at different experimental variations.

A significant difference was noticed in the fraction of fatty acids with the function of experimental conditions. Experiment No. 12 showed higher fraction of acetic acid $(3.5 \mathrm{~g} / \mathrm{L} ; 82.3 \%)$ followed by experiment No. $15,9,6$, and 18 with acetic acid concentrations ranging from 2.7 to 2.3 $\mathrm{g} / \mathrm{L}$. Acetic acid fraction varied between 73.14 to $82.36 \%$ among the first five experimental variations studied which showed VFA $>2.0 \mathrm{~g} / \mathrm{L}$. Butyric acid fraction varied between 15.22 to $21.58 \%$, while propionic acid fraction varied between 2.4 to $6.8 \%$. The observed distribution of VFA composition can be explained by the adopted operating conditions (Eastman and Ferguson, 1981; Dahiya et al., 2015). In this study, since the experiments were maintained with the same kind of wastewater, the 
differences in metabolic pathways caused by the operational parameters mainly determined the distribution of VFA.

DOA represents the extent of acidification achieved due to the production of carboxylic acids in relation to COD removal (Eq. 2). Individual fatty acids concentration influence DOA to a larger extent. It is significant to note that the highest DOA observed was with experiment No. $16(62 \%)$ followed by experiment No. 11 (53\%), experiment No. 12/17 (51\%), and experiment No. $13(50 \%)$ which all were operated with pretreated biocatalyst (L1) and in the presence of bicarbonate (L2 or L3) (Fig. 6). More specifically, first four experimental sets were operated at $\mathrm{pH} 8.5$ or 6.0 and with reasonably good organic loads (L2 and L3).

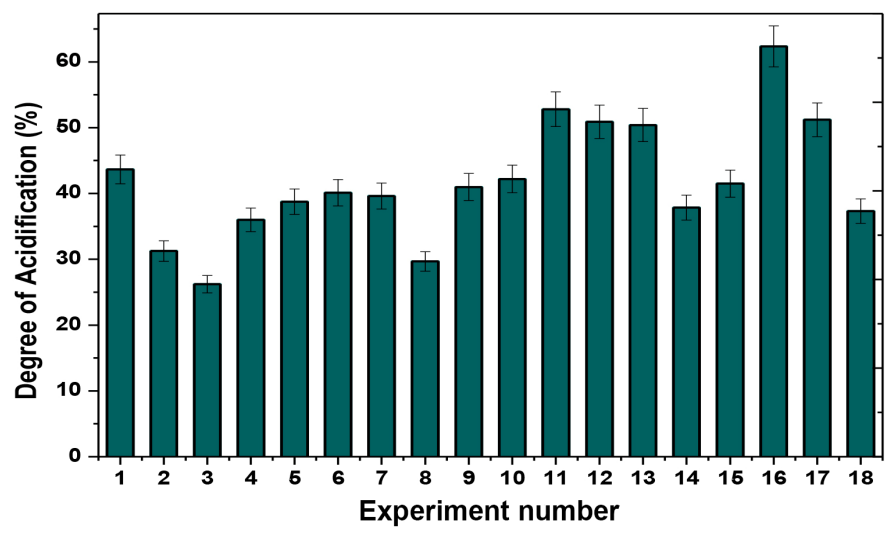

Fig.6. Degree of acidification (DOA) at different experimental conditions.

\subsection{Factors interaction}

Understanding the interactions of various factors in combination is also necessary to optimize any processes. Taguchi-based DOE approach assists in studying the interactions (as severity index: SI) of different factors to enumerate the influence of two individual factors at various levels. The relative interactions of the factors during the acidogenic process are depicted in Table 7. SI more than $50 \%$ was considered for analysis and discussion. CHP showed a significant SI with sulphate when interacting with nitrates $(76.62 \%)$, molybdenum $(76.25 \%)$, and biocatalyst (51.04\%). Sulfate under acidogenic condition functions as an electron acceptor to create a thermodynamically-favorable condition and also facilitates additional buffering to the system. Sulfate plays a vital role in the growth of $\mathrm{H}_{2}$-producing bacteria (Armstrong, 2004). Hydrogenases catalyze the oxidation of $\mathrm{H}_{2}$ or the reduction of proton contains $[\mathrm{Fe}-\mathrm{S}]$ clusters to store and transport electrons and therefore, an appropriate sulfate concentration is necessary to control hydrogenase activity (Armstrong, 2004). An increase in $\mathrm{H}_{2}$ production at high sulfate concentrations might improve hydrogenases activity. $\mathrm{pH}$ interaction with phosphates $(66.67 \%)$, bicarbonates $(56.02 \%)$. and biocatalyst $(54.66 \%)$ also showed marked influence on the $\mathrm{H}_{2}$ production. Production of fatty acid during acidogenic fermentation drops the system $\mathrm{pH}$ due to feedback inhibition. Extreme $\mathrm{pH}$ inhibits the activity of Fe-hydrogenase and also alters membrane charge, which shows negative effects on $\mathrm{H}_{2}$ production. Bacterial growth at neutral $\mathrm{pH}$ is favorable for hydrogenase activity as it takes longer time to reach final $\mathrm{pH}$ resulting in more $\mathrm{H}_{2}$ production due to increase in residence buffering time. Molybdenum with sulphate $(76.25 \%)$ and nitrate $(67.67 \%)$ documented high SI. Biocatalyst interaction with $\mathrm{pH}$ $(54.66 \%)$, sulphate $(51.04 \%)$, and biocarbonates $(50.48 \%)$ also illustrated influential effects on $\mathrm{CHP} . \mathrm{H}_{2}$ production was significantly lowered at $\mathrm{pH}>6.0$ under relatively high sulfate concentration and this could be attributed to the production of $\mathrm{H}_{2} \mathrm{~S}$ by SRB that inhibited the activity of

Table 7.

The relative interactions of the investigated factors during the acidogenic process.

\begin{tabular}{lcccc}
\hline Factors & $\begin{array}{c}\text { CHP } \\
(\mathbf{L})\end{array}$ & $\begin{array}{c}\text { HCE } \\
(\mathbf{\%})\end{array}$ & $\begin{array}{c}\text { SDR } \\
\left(\mathbf{k g} \mathbf{C O D} / \mathbf{m}^{\mathbf{3}} / \mathbf{d}\right)\end{array}$ & $\begin{array}{c}\text { VFA } \\
(\mathbf{m g} / \mathbf{L})\end{array}$ \\
\hline Sulphates $\times$ Nitrates & 76.62 & 24.36 & 74.18 & - \\
Sulphates $\times$ Molybdenum & 76.25 & - & 38.42 & 62.08 \\
Nitrates $\times$ Molybdenum & 67.67 & 50.51 & 16.4 & 38.76 \\
$\mathrm{pH} \times$ Phosphates & 66.19 & 46.1 & - & 12.84 \\
$\mathrm{pH} \times$ Bicarbonates & 56.02 & - & 30.22 & 21.55 \\
Biocatalyst $\times$ pH & 54.66 & 36.46 & - & 49.17 \\
Biocatalyst $\times$ Sulphates & 51.04 & 30.06 & 35.47 & 26.96 \\
Nitrates $\times$ Phosphates & 50.86 & 16.64 & 18.69 & 50.07 \\
Biocatalyst $\times$ Bicarbonates & 50.48 & - & 60.54 & 85.63 \\
Sulphates $\times$ pH & 42.79 & 46.37 & 54.73 & 66.21 \\
Nitrates $\times$ Bicarbonates & 40.87 & - & 39.21 & 52.77 \\
Biocatalyst $\times$ Nitrates & 38.84 & 27.84 & 12.15 & 39.91 \\
Phosphates $\times$ Molybdenum & 38.72 & - & - & 37.81 \\
pH $\times$ Nitrates & 37.13 & 29.94 & - & 46.57 \\
Biocatalyst $\times$ Molybdenum & 31.95 & 43.08 & 28.09 & - \\
pH $\times$ Molybdenum & 28.01 & 24.39 & 20.33 & 72.96 \\
Sulphates $\times$ Phosphates & 27.9 & 17.37 & 17.41 & 37.41 \\
Organic load $\times$ Nitrates & 24.77 & 41.48 & 9.65 & 11.65 \\
Organic load $\times$ pH & 23.64 & 63.27 & - & - \\
Sulphates $\times$ Bicarbonates & 22.63 & 60.49 & 17.63 & 50.77 \\
Organic load $\times$ Molybdenum & - & - & 9.75 & - \\
Biocatalyst $\times$ Phosphates & - & - & 6.44 & 35.24 \\
Phosphate $\times$ Molybdenum & - & 45.94 & 66.93 & - \\
Biocatalyst $\times$ Bicarbonates & - & 41.59 & - & - \\
Biocatalyst $\times$ COD & - & 40.38 & - & - \\
Phosphates $\times$ Bicarbonates & - & 18.59 & 10.67 & 32.45 \\
Molybdenum $\times$ Bicarbonates & - & 30 & 13.94 & \\
\hline & & & & \\
& & & & \\
\end{tabular}

Please cite this article as: Sarkar O., Venkata Mohan S. Deciphering acidogenic process towards biohydrogen, biohythane and short chain fatty acids production: multi-output optimization strategy. Biofuel Research Journal 11 (2016) 458-469. DOI: 10.18331/BRJ2016.3.3.5 
$\mathrm{H}_{2}$ producing microorganisms (Chen et al., 2008). Reasonable CHP production was achieved with zero nitrates whereas minimum CHP was observed at $600 \mathrm{mg} / \mathrm{L}$.

Biocatalyst, which had the highest influence on the process individually, showed relatively low SI with nitrates $(38.84 \%)$ and phosphate $(29.36 \%)$. Increasing phosphate concentration could increase the ability of $\mathrm{H}_{2}$ producing bacteria to produce $\mathrm{H}_{2}$ to certain extent. As mentioned earlier, appropriate $\mathrm{C} / \mathrm{N}$ and $\mathrm{C} / \mathrm{P}$ ratios are fundamental for $\mathrm{H}_{2}$ production. In fact, the differences observed among these studies can be attributed to substrate, as well as $\mathrm{C} / \mathrm{N}$ and $\mathrm{C} / \mathrm{P}$ ratios. Comparatively, sulphates (second higher influencing factor) showed relatively low SI of $26.91 \%$ (at L1; column 1) with organic load and nitrate (third highest influencing factor) $20.48 \%$ (at L3, L2; column 3). In the case of HCE, interaction of COD with $\mathrm{pH}(63.27 \%)$, sulphate with bicarbonate $(60.49 \%)$, and nitrates with molybdenum $(50.51 \%)$ showed marked influences. The trace molybdenum forms the catalytic centre of a large variety of enzymes which includes nitrogenase, nitrate reductases, sulphite oxidase, etc. (Schwarz et al., 2009). Molybdenum has an essential role in the growth of anaerobic microorganisms, including methanogens and hyper thermophilc archaea, gram-positive bacteria, sulfate reducers, and nitrogen-fixing bacteria (Jiang, 2006). Moreover, molybdenum is a co-factor for enzyme nitrogenase which is responsible for the production of $\mathrm{H}_{2}$ (Eroglu et al., 2002; Salleh et al., 2004). It is evident from the SI, that interaction influence of CHP was relatively higher. SDR showed a relatively higher interaction of sulphate with nitrates $(74.81 \%)$ followed by biocatalyst with bicarbonate (60.54\%), and sulphate with $\mathrm{pH}(54.73 \%)$.
The relative interactive effects of the factors on the VFA production led to interesting observations (Table 7). Bicarbonate interaction with biocatalyst showed a higher SI $(85.63 \%)$ on VFA production followed by $\mathrm{pH}$ with molybdenum $(72.96 \%)$, sulphate $(66.21 \%)$, and molybdenum $(62.08 \%)$. Interaction of sulphate with molybdenum $(50.77 \%)$, and nitrates with bicarbonate $(52.77 \%)$ also showed a marked influence on the VFA synthesis. In the case of SDR, the interaction of sulphate with nitrogen showed a higher SI $(74.18 \%)$ followed by molybdenum and phosphates (66.93\%), biocarbonate and biocatalyst (60.54\%), and sulphate and $\mathrm{pH}(54.73 \%)$. It is evident from the interaction behavior on substrate degradation that the requirement for nutrient was essential. On the whole, experiment No. 12, which was operated using the pretreated biocatalyst (L2) under acidophilic redox condition ( $\mathrm{pH} 6.0$; L1) with higher organic load (10 g COD/L; L3), bicarbonates ( $1 \mathrm{~g} / \mathrm{L} ; \mathrm{L} 3)$, sulphates $(250 \mathrm{mg} / \mathrm{l} ; \mathrm{L} 2)$ and nitrates $(300 \mathrm{mg} / \mathrm{l} ; \mathrm{L} 2)$ concentrations (in the absence of phosphate and molybdenum),

\subsection{Optimum conditions}

It is evident from the ANOVA results that all the factors and interactions considered in the experimental design were statistically significant at 95\% confidence limit (F-ratios) (Tables 7, 8, and 9). The experimental degree of freedom (DOF) was 17. Organic load documented the maximum contribution $(79.0 \%)$ on VFA production, followed by biocatalyst $(39.35 \%)$ at the individual level (Table 8$)$. Organic load

Table 8.

Analysis of variance (ANOVA) pertaining to VFA production.

\begin{tabular}{|c|c|c|c|c|c|c|c|}
\hline $\begin{array}{l}\text { Severity } \\
\text { index }\end{array}$ & Factor & DOF & Sum of squares (S) & Variance (V) & F ratio $(\mathbf{F})$ & Pure sum (S') & $\mathbf{P}(\%)$ \\
\hline 1 & $\mathrm{COD}$ & 2 & 15586778 & 7793389 & 22.534 & 14895086 & 79.008 \\
\hline 2 & Biocatalyst & 1 & 823041 & 823041 & 2.379 & 477196 & 2.531 \\
\hline 3 & $\mathrm{pH}$ & 2 & 1020.796 & 510 & 0.001 & 0 & 0 \\
\hline 4 & Sulphates & 2 & 516539 & 258268 & 0.746 & 0 & 0 \\
\hline 5 & Nitrates & 2 & 106172 & 53086 & 0.153 & 0 & 0 \\
\hline 6 & Phosphates & 2 & 396663 & 198331 & 0.573 & 0 & 0 \\
\hline 7 & Molybdenum & 2 & 629850 & 314925 & 0.91 & 0 & 0 \\
\hline \multirow[t]{3}{*}{8} & Bicarbonates & 2 & 100806 & 50403 & 0.145 & 0 & 0 \\
\hline & Other errors & 2 & 691691 & 345845 & 22.534 & 14895086 & 18.461 \\
\hline & Total & 17 & 18852564 & - & - & - & 100 \\
\hline
\end{tabular}

Table 9.

Analysis of variance (ANOVA) pertaining to cumulative hydrogen production (CHP).

\begin{tabular}{|c|c|c|c|c|c|c|c|}
\hline $\begin{array}{l}\text { Severity } \\
\text { index }\end{array}$ & Factor & DOF & Sum of squares (S) & Variance (V) & $F$ ratio $(F)$ & Pure sum (S') & $\mathbf{P}(\%)$ \\
\hline 1 & Biocatalyst & 1 & 2.739 & 2.739 & 0.415 & 0 & 0 \\
\hline 2 & Sulphates & 2 & 0.283 & 0.141 & 0.021 & 0 & 0 \\
\hline 3 & Organic Load & 2 & 28.14 & 14.07 & 2.135 & 14.964 & 23.1 \\
\hline 4 & $\mathrm{pH}$ & 2 & 0.414 & 0.207 & 0.031 & 0 & 0 \\
\hline 5 & Nitrates & 2 & 1.346 & 0.673 & 0.102 & 0 & 0 \\
\hline 6 & Phosphates & 2 & 7.319 & 3.659 & 0.555 & 0 & 0 \\
\hline 7 & Molybdenum & 2 & 6.538 & 3.269 & 0.496 & 0 & 0 \\
\hline \multirow[t]{3}{*}{8} & Bicarbonates & 2 & 4.669 & 2.334 & 0.354 & 0 & 0 \\
\hline & Other errors & 2 & 13.174 & 6.587 & - & - & 76.8 \\
\hline & Total & 17 & - & - & - & - & 100 \\
\hline
\end{tabular}


Table 10.

Optimum conditions and their contributions to acidogenic output parameters.

\begin{tabular}{|c|c|c|c|c|}
\hline $\begin{array}{l}\text { Severity } \\
\text { index }\end{array}$ & Factor & CHP & HCE & SDR \\
\hline 1 & Biocatalyst & Treated & Treated & Untreated \\
\hline 3 & Organic load (g COD/L) & 10 & 3 & 1 \\
\hline 5 & Nitrates $(\mathrm{mg} / \mathrm{L})$ & 0 & 0 & 600 \\
\hline 6 & Phosphates (mg/L) & 0 & 0 & 1000 \\
\hline 7 & Molybdenum (mg/L) & 0 & 0 & 10 \\
\hline 8 & Bicarbonates (mg/L) & 500 & 500 & 1000 \\
\hline
\end{tabular}

showed a marked influence on the $\mathrm{H}_{2}$ production. Organic load and biocatalyst had major roles in the production of both $\mathrm{H}_{2}$ and VFA. Optimum conditions to achieve higher $\mathrm{H}_{2}$ production include the requirement for pretreated biocatalyst with high carbon load, acidophilic redox condition, sulphate, and biocarbonate, leading to an increment of 58\% (Table 10). Pretreated biocatalyst was the most significant factor influencing the acidogenic fermentation specific to $\mathrm{H}_{2}$ and VFA production. Sulphate presence showed a marked influence on the $\mathrm{H}_{2}$ production rather than VFA production or substrate degradation. Basic redox operation was found in favor of VFA production. Higher organic loads led to higher productivity, but conversion efficiency was reduced for $\mathrm{H}_{2}$ production. Buffering capacity (induced in the presence of bicarbonate) was a requirement for all the acidogenic operations. The specific optimum conditions determined based on the findings of the present study (Table 10), led to more or less $50 \%$ increment in output performance parameters, viz., VFA production, SDR, $\mathrm{HCE}$, and CHP.

\subsection{Data envelopment analysis (DEA)-combined influence}

Data envelopment analysis (DEA) is a linear program based method which facilitates measuring relative performance of a system having multiple input and outputs parameters (where comparisons are difficult). This novel approach measures, compares the performance, and analyzes the results obtained by interpreting the outputs of a given system based on the relative efficiency (not based on the absolute efficiency) using a graphical approach (Venkata Mohan et al., 2008). The relative efficiency of a system is calculated based on the comparison between current performances of the system and the best possible performance the system could be reasonably expected to achieve (Eq. 4):

Relative efficiency $=[(X / Y) \times 100]$

where, $X$ represents the length of the line from the origin to the point obtained by plotting two ratios of the system and $Y$ denotes length of the line from the origin through the point obtained by the system to the efficient frontier.

In this study, the relative performance was assessed by considering output parameters, viz., $\mathrm{H}_{2}$, VFA, and SDR as depicted in Figure 7. Relative efficiency of any given systems indicates the extent to which other systems can improve their performance. Experiment No. $12(\mathrm{pH}, 6$; pretreated biocatalyst; $10 \mathrm{~g} \mathrm{COD} / \mathrm{L}$; bicarbonate $1 \mathrm{~g} / \mathrm{L}$; sulphate $250 \mathrm{mg} / \mathrm{L}$; nitrate $300 \mathrm{mg} / \mathrm{L}$ ) and experiment No. $16(\mathrm{pH}, 8.5$; pretreated biocatalyst; $3 \mathrm{~g} \mathrm{COD} / \mathrm{L}$ : sulphates $1 \mathrm{~g} / \mathrm{L}$; nitrates $300 \mathrm{mg} / \mathrm{L}$; phosphate $1 \mathrm{~g} / \mathrm{L}$; bicarbonate $500 \mathrm{mg} / \mathrm{L}$ ) were positioned on the efficient frontier lines with a relative efficiency of $100 \%$ illustrating the efficient acidogenic process with respect to $\mathrm{H}_{2}$ and VFA production in combination. Seven experimental variations studied showed

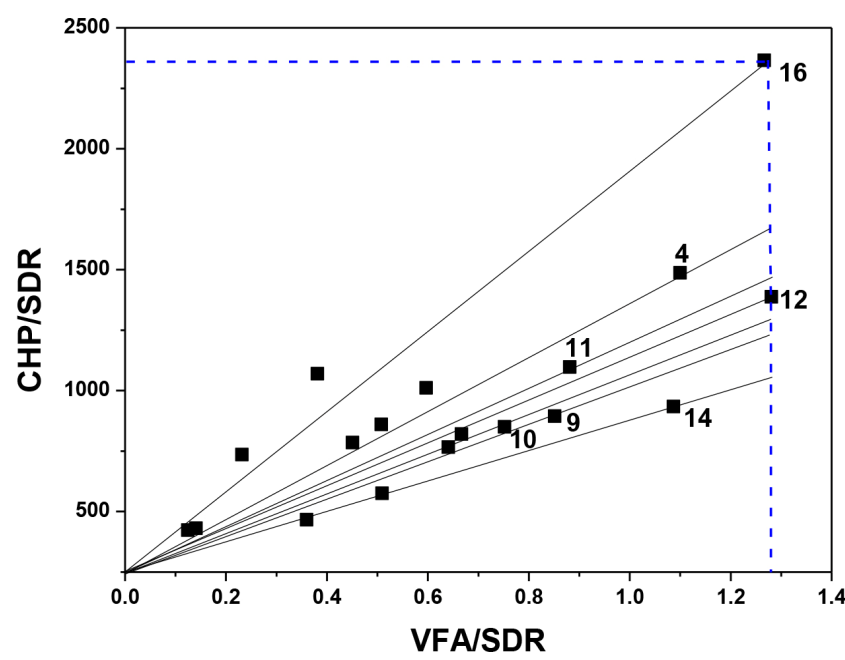

Fig.7. Experimental data expressed in DEA format to calculate the relative efficiency of CHP/SDR vs. CHP/SDR

relative efficiencies of above 50\%. Experiment No. 4 and No. 14 showed relative efficiencies of above $80 \%$ while experiment No.11 and No. 9 documented relative efficiencies of above $60 \%$.

\subsection{Validation study}

Validation experiment designed with optimum operating conditions (pretreated biocatalyst, $10 \mathrm{~g} \mathrm{COD} / \mathrm{L}, \mathrm{pH} 6$, bicarbonate $0.5 \mathrm{~g} / \mathrm{L}$, sulphate 1 $\mathrm{g} / \mathrm{L})$ were performed in a semi-pilot scale hybrid bioreactor $(40 \mathrm{~L})$ with a gas holding capacity of $5 \mathrm{~L}$. The bioreactor was designed to operate in the up-flow mode (L/D ratio, 2) and was filled with coir pith as fixed bed packing material to support the formation of biofilm. The operation under the designed conditions resulted in CHP of $57.6 \mathrm{~L}$ with HCE of $44.4 \%$ (Table 11). VFA production of $3.7 \mathrm{~g} / \mathrm{L}$ was recorded with a marginal drop in acidification due to the fact that the conditions were specifically adopted for $\mathrm{H}_{2}$ production. SDR decreased to $2.27 \mathrm{~kg} \mathrm{COD} / \mathrm{m} / \mathrm{d}$ with a specific $\mathrm{H}_{2}$ yield (SHY) of $398 \mathrm{~L} \mathrm{H}_{2} / \mathrm{kg} \mathrm{COD}$. Dehydrogenase activity $(3.2 \mu \mathrm{g} / \mathrm{mL}$ of toluene) well correlated with the optimum parameters towards acidogenesis. $\mathrm{H}_{2}$ production from wastewater offers a significant advantage of using mixed microbiome. This is ascribed to the persistent operational flexibility, stability as well as robustness, manifestation of 
diverse biochemical functions, and the possibility to use a wide range of substrates.

Table 11.

The result of the validation study carried out using the optimum values of the selected factors*.

\begin{tabular}{ll}
\hline Parameters & Value \\
\hline VFA $(\mathrm{g} / \mathrm{L})$ & 3.7 \\
Acetic acid $(\mathrm{g} / \mathrm{L})$ & 1.4 \\
Butyric acid $(\mathrm{g} / \mathrm{L})$ & 0.54 \\
Propionic acid $(\mathrm{g} / \mathrm{L})$ & 0.14 \\
$\mathrm{pH}$ & 4.5 \\
Dehydrogenase activity $(\mu \mathrm{g} / \mathrm{mL}$ of toluene) & 3.2 \\
$\mathrm{HCE}(\%)$ & 44.4 \\
$\mathrm{DOA}(\%)$ & 27 \\
$\mathrm{SDR}\left(\mathrm{kg} \mathrm{COD} / \mathrm{m}^{3} / \mathrm{d}\right)$ & 2.27 \\
$\mathrm{SHY}\left(\mathrm{L} \mathrm{H} / / \mathrm{kg} \mathrm{COD}_{\mathrm{R}}\right)$ & 206.9 \\
$\mathrm{COD}_{\mathrm{R}}$ efficiency $(\%)$ & 76 \\
\hline
\end{tabular}

*Operating conditions - pretreated biocatalyst; $\mathrm{COD}(10 \mathrm{~g} / \mathrm{L}) ; \mathrm{pH}(6.0)$; bicarbonate $(0.5 \mathrm{~g} / \mathrm{L})$; sulphates $(1.0 \mathrm{~g} / \mathrm{L})$.

\section{Conclusions}

The functional role of selected factors on acidogenic process provided an important insight into the process optimization by understanding their roles on $\mathrm{H}_{2}$, biohythane, and VFA production along with on waste treatment. Moreover, the Taguchi methodology served as a systematic mathematical approach to understand the acidogenic process only with a few well-defined experimental sets. It was found that each selected factor with its variable concentrations had a great influence on the acidogenic by-products. Pretreated biocatalyst along with higher COD load and bicarbonates presence led to enhanced CHP, whereas $\mathrm{pH}$ in combination with sulphate, nitrate, and bicarbonates increased the DOA. Concentration of COD showed a significant influence on the performance of acidogenic fermentation specific to VFA and $\mathrm{H}_{2}$ production. This methodology also identified the interactive effects of the selected factor that could be used for optimization purposes. On the whole, $\mathrm{pH}$, organic load, and biocatalyst nature were shown to exert significant effects on acidogenic fermentation as well as on metabolic end products. Basic and neutral redox conditions and pretreated biocatalyst depicted higher impacts on $\mathrm{H}_{2}$ and/or VFA production. On the contrary, neutral redox conditions and untreated biocatalyst had higher impacts on substrate degradation. Nutrients requirements was essential for substrate degradation rather than $\mathrm{VFA} / \mathrm{H}_{2}$ production. The present study also illustrated the feasibility of combined biogas production (in form of biohythane as CNG alternative) using acidogenic fermentation. DEA was also successfully used to assess the relative performance of the system with multiple output parameters.

\section{Acknowledgments}

The authors are grateful to the Director of CSIR-IICT for his kind support in carrying out this work. Research was funded by the Department of Biotechnology (DBT;13642/BBE/117/80/2015) and Council of Scientific and Industrial Research (CSIR; CSC 0113 and ESC 0108).

\section{References}

[1] APHA, 1998. Standard methods for the examination of water and wastewater. 20th Ed. American Public Health Association, American Water Works Association \& Water Environment Federation, Washington D.C.

[2] Armstrong, F.A., 2004. Hydrogenases: active site puzzles and progress. Curr. Opin. Chem. Biol. 8(2), 133-140.
[3] Jiang, B., 2006. The effect of trace elements on the metabolisms of anaerobic microbial consortia, Wageningen University, Wageningen, The Netherlands.

[4] Bastidas-Oyanedel, J.R., Bonk, F., Thomsen, M.H., Schmidt, J.E., 2015. Dark fermentation biorefinery in the present and future (bio) chemical industry. Rev. Environ. Sci. Biotechnol. 14(3), 473-498.

[5] Chen, C.C., Chen, H.P., Wu, J.H., Lin, C.Y., 2008. Fermentative hydrogen production at high sulfate concentration. Int. J. Hydrogen Energy. 33(5), 1573-1578.

[6] Chiranjeevi, P., Naresh Kumar, A., Venkata Mohan, S., 2014 Critical assessment of biofilm and suspended growth reactor configurations for acidogenicbiohydrogen production using wastewater as a function of redox microenvironment. Int. J. Hydrogen Energy. 39(14), 7561-7571.

[7] Dahiya, S., Sarkar, O., Swamy, Y.V., Venkata Mohan, S., 2015. Acidogenic fermentation of food waste for volatile fatty acid production with co-generation of biohydrogen. Bioresour. Technol. $182,103-113$.

[8] Eastman, J.A., Ferguson, J.F., 1981. Solubilization of particulate organic carbon during the acid phase of anaerobic digestion. J. Water Pollut. Control Fed. 53(3), 352 -366.

[9] Elreedy, A., Tawfik, A., Enitan, A., Kumari, S., Bux, F., 2016. Pathways of 3-biofules (hydrogen, ethanol and methane) production from petrochemical industry wastewater via anaerobic packed bed baffled reactor inoculated with mixed culture bacteria. Energy Convers. Manage. 122, 119-130.

[10] Eroglu, E., Gunduz, U., Yucel, M., Eroglu, I., 2011. Effect of iron and molybdenum addition on photofermentative hydrogen production from olive mill wastewater. Int. J. Hydrogen Energy. 36(10), 5895-5903.

[11] Fulton, J., Marmaro, R.W., Egan, G.J., 2010. System for producing a hydrogen enriched fuel. US patent 7721682

[12] Goud, R.K., Venkata Mohan, S., 2012. Acidic and alkaline shock pretreatment to enrich acidogenic biohydrogen producing mixed culture: long term synergetic evaluation of microbial inventory, dehydrogenase activity and bio-electro kinetics. RSC Adv. 2(15), 6336-6353.

[13] Hwang, J.H., Choi, J.A., Abou-Shanab, R.A.I., Bhatnagar, A., Min, B., Song, H., Kumar, E., Choi, J., Lee, E.S., Kim, Y.J., Um, S., 2009. Effect of $\mathrm{pH}$ and sulfate concentration on hydrogen production using anaerobic mixed microflora. Int. J. Hydrogen Energy. 34(24), 9702-9710.

[14] Goud, R.K., Venkata Mohan, S., 2012b. Regulating biohydrogen production from wastewater by applying organic load-shock: change in the microbial community structure and bio-electrochemical behavior over long-term operation. Int. J. Hydrogen Energy. 37(23), 17763-17777.

[15] Khanal, S.K., Chen, W.H., Li, L., Sung, S., 2004. Biological hydrogen production: effects of $\mathrm{pH}$ and intermediate products. Int. J. Hydrogen Energy. 29(11), 1123-1131

[16] Kim, D.H., Kim, S.H., Han, S.K., Shin, H.S., 2006. Performance of pilot-scale $\mathrm{H}_{2}$ fermenter: $\mathrm{C} / \mathrm{N}$ ratio effect and alkaline shock treatment. J. Environ. Eng. Manage. 16(5), 327-331.

[17] Lin, C.Y., Lay, C.H., 2004. Carbon/nitrogen-ratio effect on fermentative hydrogen production by mixed microflora. Int. J. Hydrogen Energy. 29(1), 41-45.

[18] Liu, Q., Chen, W., Zhang, X., Yu, L., Zhou, J., Xu, Y., Qian, G., 2015. Phosphate enhancing fermentative hydrogen production from substrate with municipal solid waste composting leachate as a nutrient. Bioresour. Technol. 190, 431-437.

[19] Liu, Z., Zhang, C., Lu, Y., Wu, X., Wang, L., Wang, L., Han, B., Xing, X.H., 2013. States and challenges for high-value biohythane production from waste biomass by dark fermentation technology. Bioresour. Technol. 135, 292-303.

[20] McDowall, J.S., Murphy, B.J., Haumann, M., Palmer, T. Armstrong, F.A., Sargent, F., 2014. Bacterial formatehydrogenlyase complex. Proc. Natl. Acad. Sci. 111, 3948-3956.

[21] Menetrez, M.Y., 2014. Meeting the U.S. renewable fuel standard: a comparison of biofuel pathways. Biofuel Res. J. 1(4), 110-122. 
[22] Mohanakrishna, G., Venkata Mohan, S., 2013. Multiple process integrations for broad perspective analysis of fermentative $\mathrm{H}_{2}$ production from wastewater treatment: technical and environmental considerations. Appl. Energy. 107, 244-254.

[23] Mohanakrishna, G., Venkata Subhash, G., Venkata Mohan, S., 2011. Adaptation of biohydrogen producing reactor to higher substrate load: redox controlled process integration strategy to overcome limitations. Int. J. Hydrogen Energy. 36(15), 8943-8952.

[24] Nigam, P.S., Singh, A., 2011. Production of liquid biofuels from renewable resources. Prog. Energy Combust. Sci. 37(1), 52-68.

[25] Pasupuleti, S.B., Sarkar, O., Venkata Mohan, S., 2014. Upscaling of biohydrogen production process in semi-pilot scale biofilm reactor: evaluation with food waste at variable organic loads. Int. J. Hydrogen Energ. 39(14), 7587-7596.

[26] Pasupuleti, S.B., Venkata Mohan, S., 2015. Acidogenic hydrogen production from wastewater: process analysis with the function of influencing parameters. Int. J. Energy Res. 39(8), 1131-1141.

[27] Popov, V.O., Lamzin, V.S., 1994. NAD (+)-dependent formate dehydrogenase. Biochem. J. 301(Pt3), 625-643.

[28] Rodríguez, M.J., Garza, G.Y., Aguilera, C.A., Martínez, A.S.Y., Sosa, S.G.J., 2005. Influence of nitrate and sulfate on the anaerobic treatment of pharmaceutical wastewater. Eng. Life Sci. 5(6), 568-573.

[29] Salleh, S.F., Kamaruddin, A., Uzir, M.H., Mohamed, A.R., 2014. Effects of cell density, carbon dioxide and molybdenum concentration on biohydrogen production by Anabaena variabilis ATCC 29413. Energy Convers. Manage. 87, 599-605.

[30] Sarkar, O., Kannaiah Goud, R., Venkata Subhash, G., Venkata Mohan, S., 2013. Relative effect of different inorganic acids on selective enrichment of acidogenic biocatalyst for fermentative biohydrogen production from wastewater. Bioresour. Technol. 147, 321-331.

[31] Sarkar, O., Kumar, A.N., Dahiya, S., Krishna, K.V., Yeruva, D.K., Venkata Mohan, S., 2016. Regulation of acidogenic metabolism towards enhanced short chain fatty acid biosynthesis from waste: metagenomic profiling. RSC Adv. 6, 18641-18653.

[32] Schwarz, G., Mendel, R.R., Ribbe, M.W., 2009. Molybdenum cofactors, enzymes and pathways. Nature 460, 839-847.

[33] Singhania, R.R., Patel, A.K., Christophe, G., Fontanille, P., Larroche, C., 2013. Biological upgrading of volatile fatty acids, key intermediates for the valorization of biowaste through dark anaerobic fermentation. Bioresour. Technol. 145, 166-174.

[34] Srikanth, S., Venkata Mohan, S., 2012. Regulatory function of divalent cations in controlling the acidogenic biohydrogen production process. RSC Adv. 2(16), 6576-6589.

[35] Srikanth, S., Venkata Mohan, S., 2014. Regulating feedback inhibition caused by the accumulated acid intermediates during acidogenic hydrogen production through feed replacement. Int. J. Hydrogen Energy. 39(19), 10028-10040.
[36] Thang, V.H., Kanda, K., Kobayashi, G., 2010. Production of acetone-butanol-ethanol (ABE) in direct fermentation of cassava by Clostridium saccharoperbutylacetonicum N1-4. Appl. Biochem. Biotechnol. 161(1-8),157-170

[37] Trad, Z., Akimbomi, J., Vial, C., Larroche, C., Taherzadeh, M.J. Fontaine, J.P., 2015. Development of a submerged anaerobic membrane bioreactor for concurrent extraction of volatile fatty acids and biohydrogen production. Bioresour. Technol. 196, 290-300.

[38] Van Aarle, I.M., Perimenis, A., Lima-Ramos, J., de Hults, E. George, I.F., Gerin, P.A. 2015. Mixed inoculum origin anc lignocellulosic substrate type both influence the production of volatile fatty acids during acidogenic fermentation. Biochem. Eng. J. 103, 242-249.

[39] Van Ginkel, S.W., Oh, S.E., Logan, B.E., 2005. Biohydrogen gas production from food processing and domestic wastewaters. Int. J. Hydrogen Energy. 30(15), 1535-1542.

[40] Venkata Mohan, S., 2009. Harnessing of biohydrogen from wastewater treatment using mixed fermentative consortia: process evaluation towards optimization. Int. J. Hydrogen Energy. 34(17), 7460-7474.

[41] Venkata Mohan, S., Bhaskar, Y.V., Krishna, T.M., Rao, N.C., Babu, V.L., Sarma, P.N., 2007. Biohydrogen production from chemica wastewater as substrate by selectively enriched anaerobic mixed consortia: influence of fermentation $\mathrm{pH}$ and substrate composition. Int. J. Hydrogen Energy. 32, 2286-2295.

[42] Venkata Mohan, S., Babu, V.L., Sarma, P.N., 2008. Effect of various pretreatment methods on anaerobic mixed microflora to enhance biohydrogen production utilizing dairy wastewater as substrate. Bioresour. Technol. 99(1), 59-67.

[43] Venkata Mohan, S., Nikhil, G.N., Chiranjeevi, P., Nagendranatha Reddy, C., Rohit, M.V., Kumar, A.N., Sakar, O., 2016. Waste biorefinery models towards sustainable circular bioeconomy: critical review and future perspectives. Bioresour. Technol. 215, 2-12.

[44] Wang, B., Wan, W., Wang, J., 2009. Effects of nitrate concentration on biological hydrogen production by mixed cultures. Front. Environ. Sci. Eng. China. 3(4), 380-386.

[45] Wang, Y.Y., Ai, P., Hu, C.X., Zhang, Y.L., 2011. Effects of various pretreatment methods of anaerobic mixed microflora on biohydrogen production and the fermentation pathway of glucose. Int. J. Hydrogen Energy. 36(1), 390-396.

[46] Xia, A., Jacob, A., Herrmann, C., Tabassum, M.R., Murphy, J. D., 2015. Production of hydrogen, ethanol and volatile fatty acids from the seaweed carbohydrate mannitol. Bioresour. Technol. 193, 488497. 